\title{
Chemical Constituents of Bark of Beilschmiedia kunstleri Gamble with Anticancer, Anti-Streptococcus pyogenes, Anti-Bacillus cereus and Anti Plesiomonas shigelloides Activities
}

\author{
Abbas Mollataghi, 2,* \\ ${ }^{1}$ Faculty of Science, Qom University of Technology, Qom, Iran \\ ${ }^{2}$ Department of Chemistry, Faculty of Science, University of Malaya, Kuala Lumpur 50603, Malaysia
}

\begin{abstract}
Lauraceae is a family medicinal plant whose tubers possesses antimicrobial, and cytotoxic, such as antiparasitic and anti-inflammatory special effects and has been used for the medicine in the cure of hepatitis and rheumatism. The antimicrobial activities of bioactive compounds including one neolignan; kunstlerone (1) and two alkaloids include isocaryachine (2) and noratherosperminine (3) as well as crude hexane, methanol and dichloromethane extracts were evaluated. Additionally, the effect of compounds $\mathbf{1}, \mathbf{2}$ and $\mathbf{3}$ were evaluated on A549, PC-3, A375, HT-29 and WRL-68 cell lines. In conclusion, kunstlerone 1 showed moderate cytotoxicity

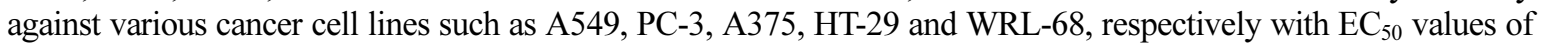
$28.02,26.78,33.78,33.65$ and $16.46 \mu \mathrm{g} / \mathrm{mL}$. The crude methanol extract showed antigrowth activity against $S$. pyogenes II and B. cereus, with MICs of $256 \mu \mathrm{g} / \mathrm{mL}$. The compounds kunstlerone (1), isocaryachine (2) and noratherosperminine (3) showed complete inhibition against $P$. shigelloides, with $\mathrm{MIC} \leq 60 \mu \mathrm{g} / \mathrm{mL}$ compare to ampicillin, as a positive control, which showed antigrowth activity against $P$. shigelloides at MIC $10 \mu \mathrm{g} / \mathrm{mL}$.
\end{abstract}

Keywords - Beilschmiedia, lauraceae, alkaloid, kunstlerone, isocaryachine, Antimicrobial, noratherosperminine

\section{Introduction}

There are more than 2500 species belonging to the Lauraceae family all over the world, spread within the subtropics and tropics of eastern Asia and South and North America. ${ }^{1}$ Many plants of Lauraceae have been affianced in folk medicine for their attractive bioactivities. For illustration, Beilschmiedia species is a source which can be treat arthritis, rheumatism, etc. ${ }^{2-7}$

In the relations of Lauraceae, most of the alkaloids are in the right place to the isoquinoline class. ${ }^{7}$ Lauraceae family is generally taking place in Southeast Asia and tropical America with 40 genera and over 2000 species. $^{8}$ In Malaysia, its contribution is about 213 species, from 16 genera. ${ }^{9}$ Aporphine alkaloids are collectively in presence but there are also a small number of indole alkaloids and quinoline alkaloids. ${ }^{10}$ This genus is over and above known to formulate a large number of biologically active compounds demodulating attractive skeletons. ${ }^{10-12}$ The lignans and neolignans consist of a class of natural plant

\footnotetext{
*Author for correspondence

Abbas Mollataghi, Faculty of Science, Qom University of Technology, Qom, Iran

Tel: +98-912-6528961; E-mail: a_mollataghi2@yahoo.com
}

products which are consequential from cinnamic acid derivatives and which are related biochemically to phenylalanine metabolism, ${ }^{13,14}$ in addition of alkaloids, flavonoids, and endiandric acid derivatives, lignans, neolignans and benzamides extracted and recognized by the Beilschmiedia species. ${ }^{15}$ Furthermore, this species has been the subject of a number of encyclopaedic articles. 10,11,16 Moreover, some of compounds such as the endiandric acid derivatives and Epoxyfuranoid lignans have shown strong antibacterial results and antitubercular activities. $^{12,17,18}$ In this study, our objective was to determine the prospective bioactivities of the crude hexane, methanol and dichloromethane extract including two alkaloids and one neolignan for cytotoxic activity on cancer cell lines and antimicrobial study.

\section{Experimental}

General experimental procedures - The optical rotations were recorded on a Jasco (Japan) P-1020 Polari meter equipped with a Sodium lamp; $\mathrm{MeOH}$ as solvent. LC-MS were obtained on an Agilent Technologies 6530 AccurateMass Q-TOF LC-MS. The ultraviolet spectra were obtained in $\mathrm{MeOH}$ on a Shimadzu UV-310 ultraviolet- 
visible spectrometer. The Fourier Transform Infrared (FTIR) spectra were obtained with $\mathrm{CHCl}_{3}(\mathrm{NaCl}$ window technique) on a Perkin Elmer 2000 instrument. The ${ }^{1} \mathrm{H}$ NMR and ${ }^{13} \mathrm{C}$-NMR spectra were recorded in deuterated chloroform on a JEOL $400 \mathrm{MHz}$ (unless stated otherwise) instrument; chemical shifts are reported in ppm on 8 scale, and the coupling constants are given in Hz. Silica gel 60, 70 - 230 mesh ASTM (Merck 7734) was used for column chromatography. Mayer's reagent was used for alkaloid screening. TLC Aluminum sheets and PTLC $\left(20 \times 20 \mathrm{~cm}\right.$ Silica gel $\left.60 \mathrm{~F}_{254}\right)$ were used in the TLC analysis. The TLC and PTLC spots were visualized under UV light (254 and $366 \mathrm{~nm}$ ) followed by spraying with Dragendorff's reagent for an alkaloid detection. All solvents, except those used for bulk extraction are AR grade.

Plant Material-Beilschmiedia kunstleri Gamble (Lauraceae), collected from Hutan Simpan sungai Tekam, Jerantut, Pahang, Malaysia was identified by Mr. Teo Leong Eng. A voucher specimen (KL 5627) is deposited at the Herbarium of the Department of Chemistry, University of Malaya, Kuala Lumpur, Malaysia and at the Herbarium of the Forest Research Institute, Kepong, Malaysia. Beilschmiedia kunstleri Gamble is a tall tree up to $12 \mathrm{~m}$ tall and $14 \mathrm{~cm}$ diameter, bark reddish brown, striated; inner bark pale brown; young shoots reddish brown; leaves simple, alternate or spinally arranged, coriaceous, from elliptic lance late to ablanceolate, apex blunt to rounded, base obtuse, $25-60 \mathrm{~cm} \times 10-18 \mathrm{~cm}$, bright green above, paler below, drying brown to deep brown, midrib raised above, secondary nerves 20 pairs, arching near the margin; P.T.O.

Natural product extraction and isolation - Air-dried bark $(1.50 \mathrm{~kg})$ of Beilschmiedia kunstleri Gamble were ground and extracted exhaustively with hexane $(5.00 \mathrm{~L})$ for 72 hours. The residual plant material was dried and left for $5 \mathrm{~h}$ after moistening with $10 \% \mathrm{NH}_{4} \mathrm{OH}$. It was then macerated with $\mathrm{CH}_{2} \mathrm{Cl}_{2}(10.00 \mathrm{~L})$ for 5 days. After filtration, the supernatant was concentrated to $500 \mathrm{~mL}$ at room temperature $\left(30^{\circ} \mathrm{C}\right)$ followed by acidic extraction with $5 \% \mathrm{HCl}$ until a negative Mayer's test result was obtained. The aqueous solution was made alkaline to $\mathrm{pH}$ 11 with $\mathrm{NH}_{4} \mathrm{OH}$ and re-extracted with $\mathrm{CH}_{2} \mathrm{Cl}_{2}$. This was followed by washing with distilled $\mathrm{H}_{2} \mathrm{O}$, dried over anhydrous sodium sulphate, and evaporation to give an alkaloid fraction $(2.90 \mathrm{~g})$. We repeat the extraction of alkaloids by using $\mathrm{MeOH}$ solvent and after acid base extraction obtained another $(35.00 \mathrm{~g})$ of crude alkaloid. The crude alkaloid from $\mathrm{CH}_{2} \mathrm{Cl}_{2}$ and $\mathrm{MeOH}$ was submitted to exhaustive column chromatography over silica gel using $\mathrm{CH}_{2} \mathrm{Cl}_{2}$ gradually enriched with methanol to yield fractions. These Fractions afforded kunstlerone (1) as neolignan, isocaryachine (2) and noratherosperminine (3) as alkaloids.

Antimicrobial activity studies - Antimicrobial activity of the extracts and isolates were investigated using the method of agar dilution. ${ }^{19}$ Provisionally, the tested compounds dissolved in either $\mathrm{CH}_{2} \mathrm{Cl}_{2}$ or $\mathrm{MeOH}$ were individually diverse with Muller Hinton (MH) broth to obtain a final volume of $2 \mathrm{~mL}$. Two-fold dilution was prepared and the solution was then transferred to the agar solution of $\mathrm{MH}$ to yield the final concentrations ranging from $256 \mu \mathrm{g} / \mathrm{mL}$, Twenty seven strains of microorganisms, refined in $\mathrm{MH}$ broth at $30{ }^{\circ} \mathrm{C}$ for $24 \mathrm{hrs}$, were diluted with $0.9 \%$ normal saline solution to regulate the cell density of $108 \mathrm{CFU} / \mathrm{mL}$.

Microorganisms - The organisms were inoculated against each plate using a multipoint inoculators and further incubated at $30^{\circ} \mathrm{C}$ for $18-48 \mathrm{hrs}$. Compounds which possessed high efficacy to inhibit bacterial cell growth were analyzed (Table 3). As aspect, these microorganism strains has assume that which strain has ability for interchanging and which sourcing the strains from different culture folders has not any effect against result the media quality results and qualification test methods.

Cell culture - All the cells that applied in this study were obtained from American Type Cell Collection (ATCC) and maintained in a $37{ }^{\circ} \mathrm{C}$ incubator with $5 \% \mathrm{CO}_{2}$ saturation. A375 human melanoma, HT-29 human colon adenocarcinoma cells and WRL-68 normal hepatic cells were maintained in Dulbecco's modified Eagle's medium (DMEM). Whereas A549 non-small cell lung cancer cells and PC-3 prostate adenocarcinoma cells were maintained in RPMI medium. Both medium were supplemented with $10 \%$ fetus calf serum (FCS), 100 units/mL penicillin, and $0.1 \mathrm{mg} / \mathrm{mL}$ streptomycin.

Cellular viability - Different cell types from above were used to find out the inhibitory effect of compounds kunstlerone (1), isocaryachine (2), noratherosperminine (3) on cell growth using the MTT assay. Briefly, cells were seeded at a density of $1 \times 10^{5}$ cells $/ \mathrm{mL}$ in a 96-well plate and incubated for 24 hours at $37^{\circ} \mathrm{C}, 5 \% \mathrm{CO}_{2}$. Next day, cells were treated with the compounds respectively and incubated for another 24 hours. After 24 hours, MTT solution at $2 \mathrm{mg} / \mathrm{mL}$ was added for 1 hour. Absorbance at $570 \mathrm{~nm}$ was measured and recorded using Plate Chameleon V microplate reader (Hidex, Turku, Finland). Results were expressed as a percentage of control giving percentage cell viability after 24 hours exposure to test agent. The potency of cell growth inhibition for each test agent was 


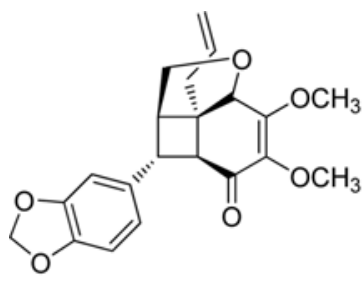

1

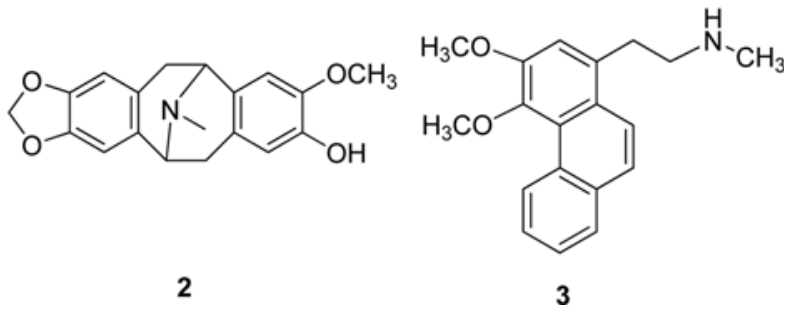

Fig. 1. Chemical structurs of bark constituents (1 - 3).

Table 1. Antimicrobial tests on crude extract of Beilschmiedia kunstleri Gamble

\begin{tabular}{llcc}
\hline \multicolumn{1}{c}{ Sample } & \multicolumn{1}{c}{ Microorganism } & Gram & MIC $(\mu \mathrm{g} / \mathrm{mL})$ \\
\hline \hline Crude hexane extract & C. diphtheriae NCTC 10356 & + & 256 \\
& C. diphtheriae NCTC 10356 & + & 256 \\
Crude dichloromethane extract & A. xylosoxidan ATCC 2706 & - & 256 \\
& S. aureus ATCC 25923 & + & 256 \\
& M lutens ATCC 10240 & + & 256 \\
Crude methanol extract & A. hydrophila & - & 256 \\
Ampicillin & B. cereus & + & 256 \\
& S. putrefaciens ATCC 8671 & - & 128 \\
& C. diphtheriae NCTC 10356 & + & 256 \\
& S. pyogenes II & + & 256 \\
& B. cereus & + & 256 \\
\end{tabular}

expressed as an $\mathrm{EC}_{50}$ value, defined as the concentration that caused a $50 \%$ loss of cell growth. Viability was defined as the ratio (expressed as a percentage) of absorbance of treated cells to untreated cells. ${ }^{20}$

\section{Result and Discussion}

In additional search for bioactive compounds and interesting chemical entities from Malaysian flora, we have performed a phytochemical study on the bark of a Malaysian Lauraceae, Beilschmiedia kunstleri Gamble, which has led to the isolation of one neolignan, kunstlerone (1), and two alkaloids consist of isocaryachine (2) and noratherosperminine (3) (Fig. 1) were isolated from the bark of this species. Recently, we have reported some constituents from the leaves and bark of Beilschmiedia species. $^{21,22}$ These compounds were obtained from the $\mathrm{CH}_{2} \mathrm{Cl}_{2}$ and $\mathrm{CH}_{3} \mathrm{OH}$ extract of the bark of B. Kunstleri.

The crude dichloromethane, hexane and methanol extracts, and the isolates (1-3) from bark of B. kunstleri Gamble were experienced and tested for antimicrobial activity against 15 strains of microorganisms by means of the agar dilution method. ${ }^{23}$ The domino effect (Table 1) give us an idea about that all the tested extracts entirely inhibit the expansion of the Gram-positive bacterium $C$. diphtheriae NCTC 10356 with MIC $256 \mu \mathrm{g} / \mathrm{mL}$. This strain was the most sensitive, as it turned out the only one inhibited by the crude hexane and dichloromethane extracts. Other microorganisms such as A. xylosoxidan ATCC 2706, S. aureus ATCC 25923, M. lutens ATCC 10240, B. cereus and A. hydrophila were wholly inhibited by the crude dichloromethane extract, with MIC $256 \mu \mathrm{g} /$ $\mathrm{mL}$. In addition, the crude methanol extract displays antigrowth activity against $S$. pyogenes II and $B$. cereus, with MICs of $256 \mu \mathrm{g} / \mathrm{mL}$.

In the current research, the antimicrobial activity of pure compounds ( 1 - 3) isolated from the dichloromethane and methanol extract was similarly evaluated. It was found (Table 1) that compounds $\mathbf{1}, \mathbf{2}$ and $\mathbf{3}$ displayed complete inhibition against $P$. shigelloides, with MIC $\leq 60$ $\mu \mathrm{g} / \mathrm{mL}$. In evaluation ampicillin, a positive be in charge, showed antigrowth doings against $P$. shigelloides at MIC $10 \mu \mathrm{g} / \mathrm{mL}$.

To evaluate the cytotoxic activity, each different compound namely kunstlerone (1), isocaryachine (2) and noratherosperminine (3) were tested with a series of different doses on A549, PC-3, A375, HT-29 and WRL68, respectively (Fig. 2). After 24 hours, cell viability was 

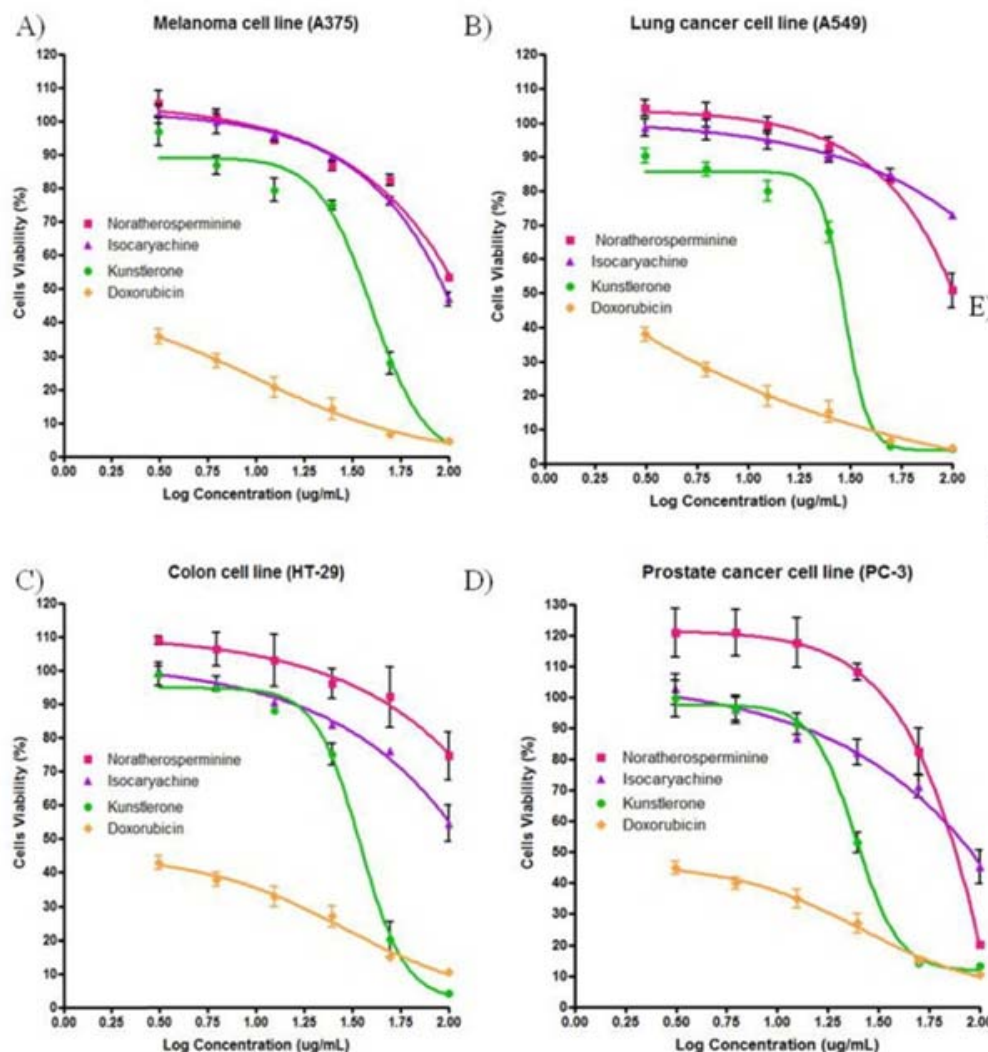

D)

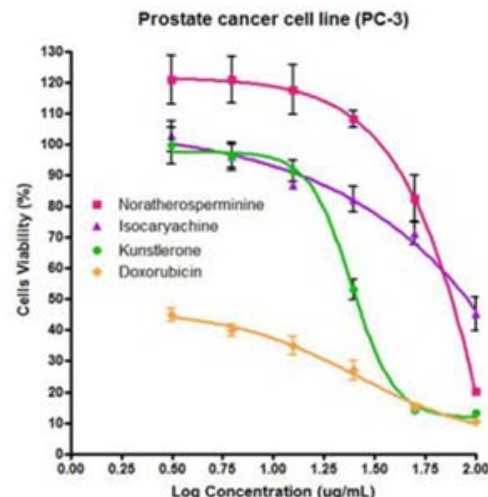

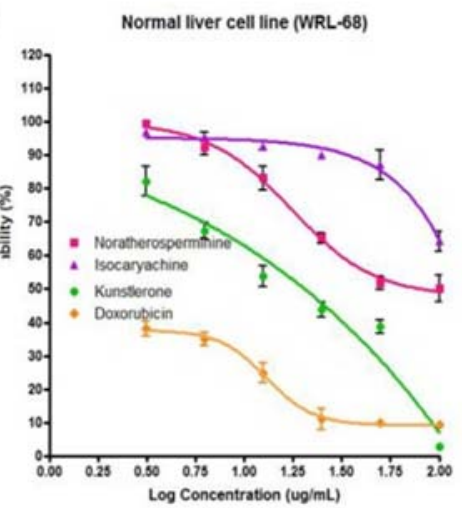

Fig. 2. Dose-response curves (using GraphPad Prism) tested with kunstlerone (1), isocaryachine (2), noratherosperminine (3) and Doxorubicin (positive control) in the MTT assays towards A) A375, B) A549, C), HT-29, D) PC-3 and E) WRL-68.

Table 2. Effect of compounds, kunstlerone (1), isocaryachine (2), noratherosperminine (3) and doxorubicin (positive control) on different cells type expressed as $\mathrm{EC}_{50}$ values in 24 hours using MTT assay

\begin{tabular}{ccccc}
\hline \hline & & & \\
\hline Cell line & kunstlerone & isocaryachine & noratherosperminine & doxorubicin \\
\hline A375 & 33.78 & 94.26 & $>100$ & 1.364 \\
A549 & 28.02 & $>100$ & $>100$ & 1.550 \\
HT-29 & 33.65 & $>100$ & $>100$ & 1.957 \\
PC-3 & 26.78 & 91.54 & 72.55 & 2.125 \\
WRL-68 & 16.46 & $>100$ & 72.37 & 1.731 \\
\hline
\end{tabular}

determined by the MTT assay. Test agents induced cell cytotoxicity in a concentration dependent manner. These dose titration curves allowed determining $\mathrm{EC}_{50}$ for the test agents towards different cell lines (Table 2).

From Fig. 2, isocaryachine (2) and noratherosperminine (3) showed no cytotoxic effect on various cell lines. On the other hand, kunstlerone (1) also showed cytotoxic effect on several of the cancer cell lines with different $\mathrm{EC}_{50}$ valuesin a concentration dependent manner. These dose titration curves allowed determining $\mathrm{EC}_{50}$ for the various compounds towards different cell lines. Kunstlerone (1) demonstrated dose-depended cytotoxic effects with $\mathrm{EC}_{50}$ values of $33.78 \pm 3.4,28.02 \pm 1.7,33.65 \pm 0.9$,
$26.78 \pm 2.3$ and $16.46 \pm 0.7 \mu \mathrm{g} / \mathrm{mL}$; in A375, A549, HT29, PC-3 and WRL-68, respectively. These results indicate that cell lines differ in their sensitivity to the same test agent, which may be determined by multiple cell type-specific signalling cascades and transcription factor activities.

Cytotoxic screening models make available important preliminary data to select plant extracts or natural compounds with potential anticancer properties. In this study, the cytotoxic effect of kunstlerone (1) was investigated by the addition of the MTT tetrazolium salt to various treated cancer cell lines. Taken together, the cytotoxic effects exerted by kunstlerone (1) as a promising 
Table 3. The pharmacopoeias list of microorganism strains to be used in the microbiological tests for confirming the growthpromoting

\begin{tabular}{cl}
\hline \hline \multicolumn{1}{c}{ Folder } & \multicolumn{1}{c}{ strains of microorganisms } \\
\hline Gram(-) bacteria & Escherichia coli ATCC 25922 \\
& Klebsiella pneumoniae ATCC 700603 \\
& Serratia marcescens A TCC 8100 \\
& Salmonella typhimurium ATCC 13311 \\
& Salmonella choleraesuis ATCC 10708 \\
& Shewanella putrefaciens ATCC 8671 \\
& Achromobacter xylosoxidans A TCC 2706 \\
& Pseudomonas aeruginosa ATCC 15442 \\
& Pseudomonas stutzeri ATCC 17587 \\
Gram(+) bacteria & Staphylococcus aureus ATCC 29213 \\
& Staphylococcus aureus ATCC 25923 \\
& Enterococcus faecalis A TCC 29212 \\
& Enterococcus faecalis ATCC 33186 \\
& Micrococcus lutens A TCC 10240 \\
& Bacillus subtilis ATCC 6633 \\
& Corynebacterium diphtheriae NCTC 10356 \\
Clinical specimens & Shigella dysenteriae \\
Gram(-) bacteria & Salmonella enteritidis type C \\
& Morganella morganii \\
& Aeromonas hydrophila \\
& Citrobacter freundii \\
& Plesiomonas shigelloides \\
Gram(+) bacteria & Streptococcus pyogenes II \\
& Bacillus cereus \\
& Listeria monocytogenes \\
& Saccharomyces cereviseae ATCC 2601 \\
& Candida albicans ATCC 90028 \\
\hline &
\end{tabular}

compound and suggest its potential as anti proliferation agent. To our knowledge, the cytotoxic potentials of kunstlerone (1) have not been examined and the underlying molecular mechanisms remain to be discovered.

In conclusion, the constituents of Beilschmiedia kunstleri grown in the Pahang, Malaysia was found to possess antimicrobial and cytotoxic activities. The crude methanol extract displays antigrowth activity and kunstlerone (1), isocaryachine (2) and noratherosperminine (3) displayed complete inhibition against $P$. shigelloides. In evaluation ampicillin, a positive be in charge of this folder, showed antigrowth against $P$. shigelloides. Kunstlerone (1) showed also moderate cytotoxicity against various cancer cell lines such as A549, PC-3, A375, HT-29 and WRL-68. Therefore, the antimicrobial and cytotoxic activity study revealed that this plant has potential bioactivity.

\section{Acknowledgements}

The authors acknowledge the financial support provided by University of Malaya Research Grant (UMRG 045/ 11BIO), Centre of Natural Products and Drugs Development (CENAR), Postgraduate Research Grant of University of Malaya (PS366/2010B) and High Impact Research (HIR) Grant of University of Malaya (F000009-21001). We also acknowledge the support provided by Faulty of science, Qom University of Technology, and Din Mat Nor and Rafly Syamsir for the plant samples and also Hairin Taha for editorial assistance.

\section{References}

(1) Simić, A.; Soković, M. D.; Ristić, M.; Grujić-Jovanović, S.; Vukojević, J.; Marin, P. D. Phytother. Res. 2004, 18, 713-717.

(2) Pudjiastuti, P.; Mukhtar, M. R.; Hadi, A.H.; Saidi, N.; Morita, H.; Litaudon, M.; Awang, K. Molecules 2010, 15, 2339-2346.

(3) Lenta, B. N.; Tantangmo, F.; Devkota, K. P.; Wansi, J. D.; Chouna, J. R.; Soh, R. C.; Neumann, B.; Stammler, H. G.; Tsamo, E.; Sewald, N. J. Nat. Prod. 2009, 72, 2130-2134.

(4) Earl, E. A.; Altaf, M.; Murikoli, R. V.; Swift, S.; O'Toole, R. BMC Complement. Altern. Med. 2010, 10, 25.

(5) Lee, K. G.; Shibamoto, T. J. Agric. Food Chem. 2002, 50, 49474952.

(6) Khan, A.; Safdar, M.; Ali Khan, M.M.; Khattak, K. N.; Anderson, R. A. Diabetes Care 2003, 26, 3215-3218.

(7) Saxton, J. E.; Bentley, K. W. The Alkaloids: The isoquinoline alkaloids: The chemical Society; 2007.

(8) Lajis, N. H. J.; Ahmad, R. Stud. Nat. Prod. Chem. 2006, 33, 10571090.

(9) Guinaudeau, H.; Leboeuf, M.; Cave, A. J. Nat. Prod. 1979, 42, 325360 .

(10) Harborne, J. B.; Mendez, J. Phytochemistry 1969, 8, 763-764.

(11) Yang, P. S.; Cheng, M. J.; Peng, C. F.; Chen, J. J.; Chen, I. S. J. Nat. Prod. 2009, 72, 53-58.

(12) Yang, P. S.; Cheng, M. J.; Chen, J. J.; Chen, I. S. Helv. Chim. Acta 2008, 91, 2130-2138

(13) Sovová, H.; Opletal, L.; Bártlová, M.; Sajfrtová, M.; Krenková, M. The Journal of supercritical fluids 2007, 42, 88-95.

(14) Jackson, D. E.; Dewick, P. M. Phytochemistry 1984, 23, 10291035.

(15) Funasaki, M.; Lordello, A. L. L.; Viana, A. M.; Santa-Catarina, C.; Floh, E. I. S.; Yoshida, M.; Kato, M. J. J. Braz. Chem. Soc. 2009, 20, 853-859.

(16) Chouna, J. R.; Nkeng-Efouet, P. A.; Lenta, B. N.; Devkota, K. P.; Neumann, B.; Stammler, H. G.; Kimbu, S. F.; Sewald, N. Phytochemistry 2009, 70, 684-688.

(17) Engler, T. A.; Wei, D.; Letavic, M. A. Tetrahedron Lett. 1993, 34, 1429-1432.

(18) Engler, T. A.; Wei, D. D.; Letavic, M. A.; Combrink, K. D.; Reddy, J. P. J. Org. Chem. 1994, 59, 6588-6599.

(19) Lee, J. C.; Kim, H. R.; Kim, J.; Jang, Y. S. J. Agric. Food. Chem. 2002, 50, 6490-6496.

(20) Braga, P. A.; Dos Santos, D. A.; De Silva, M. F.; Vieira, P. C.; Fernandes, J. B.; Houghton, P. J.; Fang, R. Nat. Prod. Res. 2007, 21, 47-55.

(21) Mollataghi, A.; Hadi, A. H. A.; Awang, K.; Mohamad, J.; Litaudon, M.; Mukhtar, M. R. Molecules 2011, 16, 6582-6590.

(22) Mollataghi, A.; Hadi, A. H. A.; Cheah, S. C. Molecules 2012, 17, 4197-4208.

(23) Okusa, P.; Penge, O.; Devleeschouwer, M.; Duez, P. J. Ethnopharmacol. 2007, 112, 476-481.

Received May 15, 2018

Revised August 28, 2018 Accepted September 3, 2018 